Abstracta Iranicacta Iranica

Revue bibliographique pour le domaine irano-aryen

Volume 42-43 | 2021

Comptes rendus des publications de 2019-2020

\title{
Michelle Langford. Allegory in Iranian cinema : the aesthetics of poetry and resistance
}

\section{Laetitia Nanquette}

\section{(2) OpenEdition}

1 Journals

\section{Electronic version}

URL: https://journals.openedition.org/abstractairanica/51907

DOI: 10.4000/abstractairanica.51907

ISSN: 1961-960X

Publisher:

CNRS (UMR 7528 Mondes iraniens et indiens), Éditions de l'IFRI

\section{Electronic reference}

Laetitia Nanquette, "Michelle Langford. Allegory in Iranian cinema : the aesthetics of poetry and resistance", Abstracta Iranica [Online], Volume 42-43 | 2021, document 1, Online since 30 December 2020, connection on 13 December 2022. URL: http://journals.openedition.org/abstractairanica/51907 ; DOI: https://doi.org/10.4000/abstractairanica.51907

This text was automatically generated on 13 December 2022.

All rights reserved 


\title{
Michelle Langford. Allegory in Iranian cinema : the aesthetics of poetry and resistance
}

\author{
Laetitia Nanquette
}

\section{REFERENCES}

Michelle Langford. Allegory in Iranian cinema: the aesthetics of poetry and resistance.

London: Bloomsbury, 2019

1 Langford studies the long tradition of allegorical expression in Persian culture and demonstrates that Iranian filmmakers who use it are not only motivated by the constraints of censorship, contrary to what has often been argued: allegory is an integral part of their aesthetics. Through powerful readings of films by iconic directors from both the pre and post-revolution period, Langford shows that allegory is a tool for their expression, that sometimes challenges the laws of the Islamic Republic's on cinema, sometimes go along with them, and in all cases, acts as an instrument of negotiation in a fluid context. Her argument that the aesthetics of allegory prompts viewers to look behind the literal level of the story for hidden meanings is convincingly argued. In her reading, allegory is thus both a mode of expression and of interpretation. Scholars working on Iranian cinema and Iranian post-revolutionary culture will find it an essential reading. 


\section{AUTHORS}

\section{LAETITIA NANQUETTE}

University of New South Wales, Sydney 